\title{
BIO-EXPLOITATION STATUS OF BOMBAY DUCK (Harpadon nehereus HAMILTON, 1822) ON TRAWL FISHERY IN TARAKAN WATERS
}

\author{
Duto Nugroho1, Ria Faizah', Andhika P.Prasetyo'and M. Badrudin² \\ ${ }^{1}$ Research Center for Fisheries Management and Conservation, Jakarta \\ ${ }^{2}$ Fisheries Specialist at the IMACS-USAID Project, Jakarta \\ Received; May 04-2015 Received in revised from June 19-2015; Accepted June 22-2015 \\ e-mail: dutonugroho@gmail.com
}

\begin{abstract}
North Kalimantan Province, notably Tarakan City marine waters, is one of the important fishing ground in boundary area between Indonesia and Malayasia within Sulu Sulawesi Marine Ecoregion. It produces approximately $100 \mathrm{mt} / \mathrm{yr}$ of Bombay duck (Harpadon nehereus) with valued of US\$ 750,000 . The sustainability of this fishery is a crucially concern due to its: substantial economic contribution and the, significant dependence of small-scale fishers on this species for their livelihoods. The fishing intensity has a growing threats to their habitats. To evaluate the vulnerability of individual species of might cause from over exploitation, the spawning potential ratio (SPR) approach was applied to describe the status of ibombay duck fisheries. This approach provides the ability to determine fishing mortality as reference points to ensure its sustainability. The objective of this study is to understand this fish biomass resilience to harvesting. The calculated SPR based on the value of estimated length of first capture or Lc at $208 \mathrm{~mm}$ is equivalent to the SPR of $28 \%$. With a base line of stocks are generally thought to risk recruitment declining when $S P R<20 \%$, recent finding indicated that the existing fishery can be generally described as nearly fully exploited. In recognition of this fishery has an ecological importance and socio-economic significance, the sustainable development of Bombay duck fisheries should be initiated through developing local fishery committee to provide a their local fishery management plan.
\end{abstract}

\section{KEYWORDS: Bio-exploitation, Bombay duck, Harpadon nehereus, Trawl Fishery, Tarakan}

\section{INTRODUCTION}

The Nomeior Bombay duck (Harpodon nehereus) fish is the common species of estuarine fisheries in tropical waters. The species geographically occurs in along the coast of middle-east, south Asia, southeast Asia until east coast of China and North-east of Australia (Haneda, 1950; Abe \& Pathansali, 1974; Fisher \& Bianchi, 1984; Fishbase, 2015; FAO, 2015). The role of this typical small-scale fishery is significantly supporting coastal community livelihood in several countriesalong the coast Bay of Bengal Large Marine Ecosystem such as Bangladesh (Mustafa et al., 1998; Ullah et al., 2014), India (Balli et al., 2011; Shingadia, 2013) and Pakistan (Kalhoro et al., 2013). World catch showed that the country with largest landing contribution in 1999 were India and Indonesia (FAO, 1999 in FAO, 2015) and shifted to India and Bangladesh in 2012 (FAO, 2015).

Tarakan City geographically located at $117^{\circ} 32^{\prime} \mathrm{E}-$ $3^{\circ} 26^{\prime} \mathrm{N}$, the surrounding waters is one of the North Kalimantan waters that Bombay duck (locally known as Nomei) fishery has been developed rapidly since 1990s. Interviewing with related fishers indicated that over the last decade this generates an important source of income for the coastal fishing communities. The average production of Nomeiwas estimated at approximately $100 \mathrm{mt} / \mathrm{yr}$. Such fishery production has been domesticcally traded, primarily to Java markets as part of inter-island trades. Since the year of 2000s, the local government and the local small-scale industry complain that the landings have been declining and the average size of Nomeibeing caught getting smaller (Prasetyo et al., 2014), these information leads collective action that are now demanding the exploitation level should be sustainable managed.

The one day small-scale fishers, who largely exploit the harvest able stocks for food and livelihood sare similar with such reported by Shingadia (2013) in the west coast of India. This phenomenon is increasingly interested to undertake Tarakan Bombay duck fisheries in a way of sustainable management approaches. This fishery in the surrounding marine waters of Tarakan has a valued of US $\$ 750,000$ annually (Bureau of Statistics Tarakan, 2012). The long-term fishery is a crucial concern given the following: substantial economic contribution, significant dependence of small-scale fishers for their livelihoods. Sustainability by means of the ability of an exploited stock to produce goods and services, including yields at suitable levels in the short term, while maintaining the existing stock's reproductive capacity to continue providing these goods and services into the indefinite future (Ault et al., 2008). 
Rapid expansion of exploitation has created the need of information on its biological status of this species to support their fisheries management. Study on bio-exploitation of this species were undertaken in order to describe exploitation status as part of supporting their local fisheries management plan of demersal Danish seine fisheries of Juwata village, northern part of Tarakan Island. One of the basic goals of fisheries management is to conserve sufficient potential reproductive stock to allow for sustainable exploitation. To achieve this, we use a biological approach which stocks should be managed based on maintaining certain levels or limit thresholds of Spawning Stock Biomass (SSB) as an indicator of the 'viability' of the stock.

\section{MATERIALS AND METHODS}

In this study, we extended our 2013 analyses using information on biology and population parameters of Nomei that carried out through biological discreet sampling (length frequency and maturity observation) in the Juwata fishing village and have been gathered and reported by Taufik et al. (2012) and Panggabean \& Idrus (2013). Data and information includes: catch rate of trawl survey; estimated stock density were derived from Suprapto et al., (in prep) while population parameters $(K, L \infty, F, M, L c)$ of the species determined by common approach for tropical fish stock assessment (Sparre \& Venema, 1999); Life history parameters were also generated such as gonad maturity level and fecundity, fishing habit and also length at first maturity $(\mathrm{Lm})$ using Spearman-Karber method following Udupa (1982) in Taufik et al. (2012). Growth pattern of the Nomei fish assumed to follow the Von Bertalanffy growth equation to determine length-at-age:

$$
L t=L \infty\left(1-e^{-K\left(t-t_{0}\right)}\right)
$$

From length-weight relationship, the length-weight regression ( $a$ \& b) can be obtained. Weight-at-age $\left(\mathrm{W}_{\mathrm{t}}\right)$ was obtained from converting lengths into weights using the equation:

$$
W_{t}=a \cdot L_{t}^{b}
$$

SPR can be calculated for different levels of Length at first capture $\left(\mathrm{L}_{c)}\right.$ and fishing mortality $(\mathrm{F})$ by dividing spawning stock biomass under exploitation $\left(S S B B_{f}\right)$ by pristine spawning stock biomass $\left(S S B_{f=0}\right)$ of

$$
S P R=\frac{S S B_{f}}{S S B_{f=0}}
$$

Estimate biomass was calculated at based on each converted length-age class and spawning stock biomass was simply the sum of all biomass above the age at maturity. Spawning stock biomass is calculated as:

$$
S S B=\sum_{t=t_{m}}^{t} \overline{N_{t}} \cdot \overline{W_{t}}
$$

Where $\mathrm{W}_{\mathrm{t}}$ was the average weight-at-age. Spawning stock biomass was calculated at pristine levels $\left(B_{0}\right)$ and under various management scenarios regarding length of first capture $\left(\mathrm{L}_{c}\right)$ and its fishing mortality $(\mathrm{F})$. All estimated parameters were input into a spreadsheet.

To determine the SPR at size relationship provides the core information that would ideally be available from at least one location in a species range which consisted of Natural mortality $(M)$, the von Bertalanffy Growth parameters $\left(K, L_{\infty} . t_{0}\right)$, Length-weight regression $(a, b)$ and Length of first maturity $\left(\mathrm{L}_{50}\right)$. The calculation procedures were following the equation from Ault et al. (2008) and Prince et al. (2014).

\section{RESULTS AND DISCUSSION \\ Results}

\section{The Fisheries}

The Bombay-duck fisheries catch data recorded in Indonesia since 1976. The fish mainly caught as an incidental catch of trawl and seine net fishery (Fisher \& Whitehead, 1977; Fisher \& Bianchi, 1987) and those type of gear are locally known as "dogol, cantrang and lampara dasar" (MMAF Regulation No. 42/2014). The historical annual production during the year of 1976 to 2012 tend to decrease since 1999 (Figure 1). The major contribution of the national capture fishery statistics by coastal areas were Riau East Sumatra, East Kalimantan and West Papua (DGCF, 2013).

A unique situation occurred in Tarakan and most of coastal community in eastern part of Kalimantan, which the utilization of this typical estuarine species generate and play a significant role as their seasonal livelihood. Most of coastal community involved with this fishery with dried-fish as the commercial product that widely distributed to other province and neighbor country. This typical utilization increased since fisher community adopted the application of post-harvest technology the species through fillet and drying technique introduced by Tarakan Fisheries Office, never the less the product is one of the icon of Juwata village that exist since 1990's. 


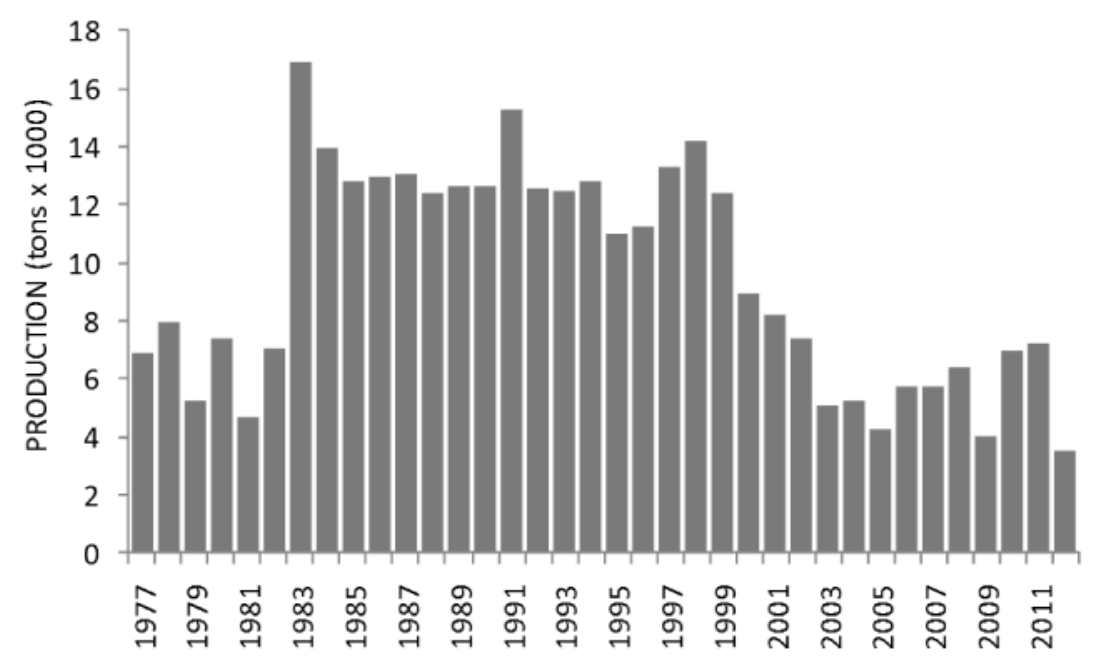

Figure 1. The annual national production of Bombay duck in 1976 to 2012.
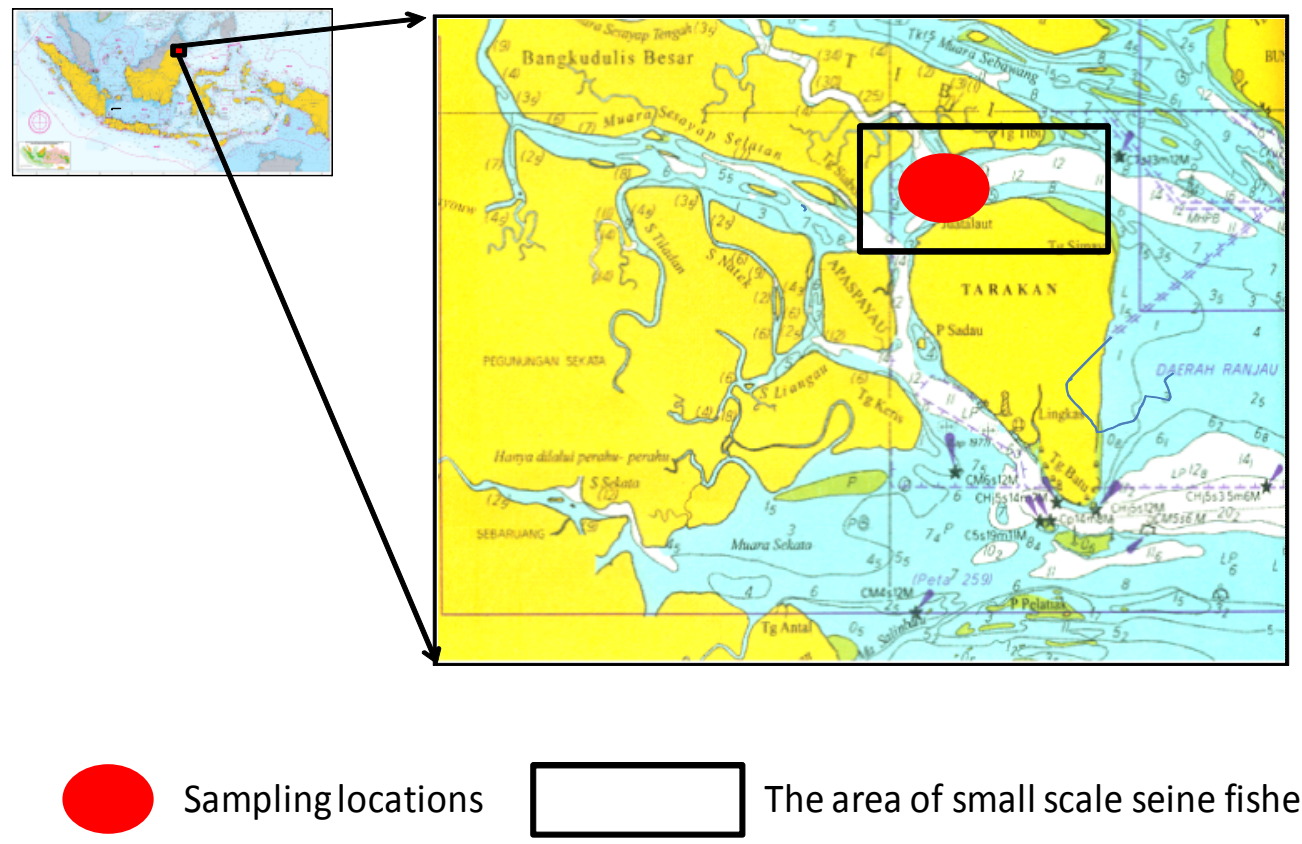

The area of small scale seine fisheries

Figure 2. Geographical location of Tarakan Island, North Kalimantan Province Source : Naval Hydrographic Institute (2000).

The area of interest located at North Kalimantan province with coordinates of $03^{\circ} 182003-03^{\circ} 202$ $003 \mathrm{~N}$ and $117^{\circ} 34200^{\prime}-117^{\circ} 382003 \mathrm{E}$, the geographical setting of its surrounding waters are shown in Figure 2. The island ecosystems found in Tarakan North Kalimantan include mangrove, estuary, sea-grass, coral reef with several river exist in coastal waters (Bureau of Statistics Tarakan 2012). It is also acknowledged that these types of coastal ecosystems provide nursery grounds, feeding grounds and spawning grounds fish species. The western part of Tarakan Island has a mangrove area that is relatively in a good condition and managed through local forest regulation on protecting this type of estuarine ecosystem (City Tarakan Government Regulation 04/2002). These estuaries provide both the nursery ground and seasonal fishing ground of trawl fisheries that target on Bombay duck (Harpodon nehereus).

\section{Stock Parameters}

Length-weight of specimens was collected from demersal Danish seine fishery in Tarakan (P4KSI, 2013) and showed that the length weight relationship of Bombay duck followed the formula of: 


$$
L=6.00 E-05 W^{2.65}
$$

The stock parameters of the Nomei fish applied on this calculation are:

$L_{\infty}=315 \mathrm{~mm}(T L)$; is the mean length of infinitely old fish or asymptotic length,

$\mathrm{K}=1.3$ year; is the curvatur parameter which determine how fast the fish approaches its $L "$,

$M=2.1$ year; is the mortality created by all other causes than fishing,

$\mathrm{Lm}=245 \mathrm{mmTL}$; is the mean length of first maturiy,

$\mathrm{LC}=208 \mathrm{mmTL}$; is the mean length of first capture.

The estimate age-length and weight von Bertalanffy growth curve were plotted. This theoretical growth curvature parameter of 1.3 year $^{-1}$ indicated that the Tarakan Bombay duck is the fast growing species with maximum age theoretically could reach of 5 years in their life cycle. The average age of first maturity $(\mathrm{Lm})$ at around 1.1 year and the average age of first capture (LC) approximately at less than 1 year. In the early stage an initial fast growth necessarily takes place during the pre-recruitment and its larval stages. In pre adult stages (less than $24.5 \mathrm{~cm}$ TL or 1 year the fisheries play a significant role of its fishing mortality the growth rate were slower. The adult stage were the size approximately at $30 \mathrm{cmTL}$ their growth tend to stabilize (Figure 3).

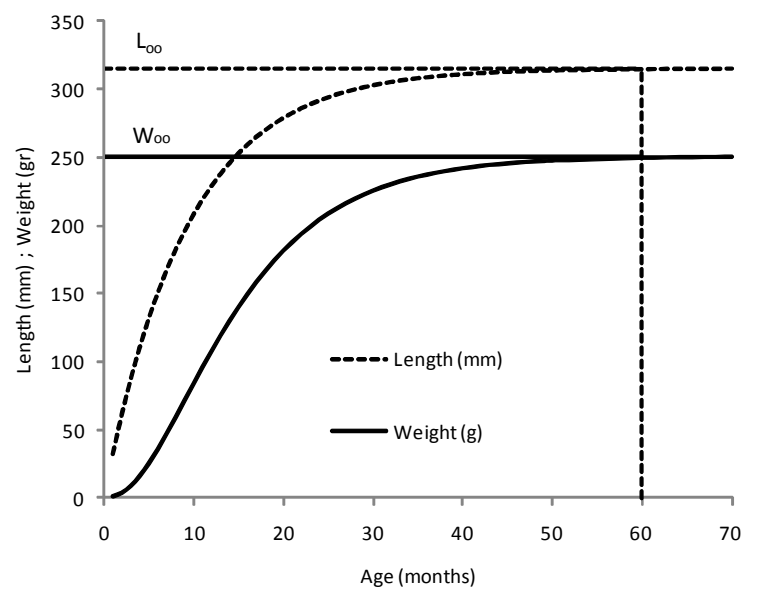

Figure 3. Age - length and weight of Harpodon nehereus in North Tarakan Waters.

The size of maturity estimates as the size class at which $50 \%$ of the stock becomes mature $\left(L_{50}\right)$ is the second essential data input in this approach. Study on estimated $\mathrm{L}_{50}$ in the area were adopted from P4KSI (2013) which indicated that the probability of mature specimens would be at average length of $24.5 \mathrm{cmTL}$ or proportionally appropriated at $\mathrm{T}_{50}$ of 14 months. Inputting these parameters into speadsheet that is specifically designed to estimate SPR, the SPR- based management scenarios can be simulated. Through the calculation, the present status of the Nomei fisheries in Tarakan and the adjacent waters can be determined. The calculated SPR of the Nomei fishery in the Tarakan and the adjacent waters based on the value of $L C=208 \mathrm{mmTL}$ is equivalent with the $\mathrm{SPR}=28.4 \%$ (Figure 4), where the fish is at the age of 10 months. This value appears above the minimum threshold of theoretical SPR to sustain the fish stocks. However the optimum long-term threshold was $40 \%$ (Woodhams et al., 2012). In order to achieve the optimum threshold, the minimum age on first capture should be at around 12 months or $220 \mathrm{~mm}$. The prediction of Spawning Stock Biomass (SSB) when length at first capture at $208 \mathrm{~mm}$ at was estimated at around $28 \%$, while the long-term SSB should be at $43 \%$ level.

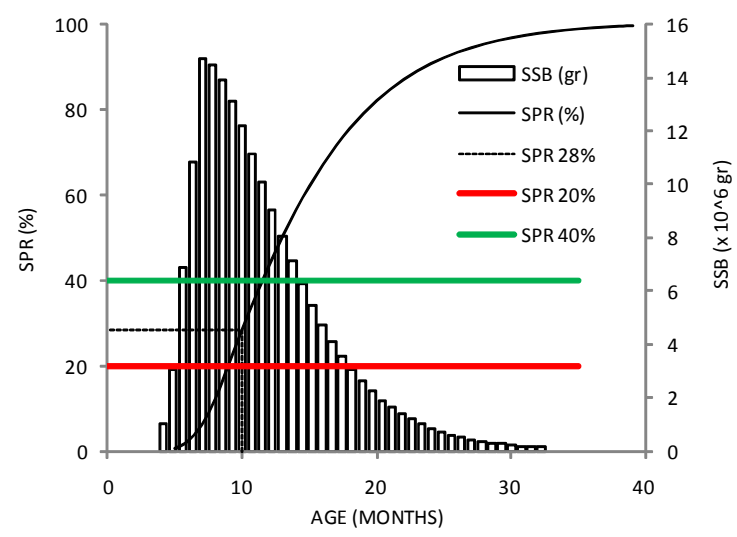

Figure 4. The estimate SPR of Harpodon nehereus in Tarakan waters.

\section{Discussion}

The Bombay duck species could be considered as targeted fish of trawl and seine net fishery in Northern part of Tarakan City. The fishing ground is typical tropical estuarine fisheries. Mangrove exist surrounding the fishing ground, the coastal water is relatively shallow and turbid. Therefore, the long-term conservation program of these coastal habitats/ ecosystems will lead to the sustainability of the fishery resources. Fishing activity is one day fishing which strongly related to lunar cycle and its coastal tidal current (Prasetyo et al., 2014). Haneda (1950) stated that most of fish were caught in early stage of its exploitation by using tidal trap. Most of the fishes and other animals are dead or dying when the nets are lifted, and only those caught last may be alive, since they are not subjected to anything but the pressure of the water. 
Some biological properties of this species were obtained elsewhere, indicated that the species has a maximum length up to $40 \mathrm{~cm}$ TL. The tropic level categorized as medium tropic level (4.2) with relatively high resilience and low vulnerability, and the species inhabit offshore on sandy mud bottom for most of the year, but also gathers in large shoals in deltas of rivers to feed during monsoons (Fishbase, 2015). The lengthbased assessment is commonly used to describe the precautionary approach on tropical fisheries assessment where fish do not carry easily birth marks on their scales or otoliths (Gulland \& Rosenberg, 1992; Valentia \& Deffeo, 1997). Spawning potential ratio could play as one of bio-exploitation indicators to compute fishery management reference points of stock status (Ault et al., 2008). This estimated value would share on developing biological reference point on long-term fisheries management plan as a benchmark to adjust harvest so that the stock remain in safe biological limit (Kohin et al., 2006) or an indicating limit of the fishery exploitation to stock shelf reproduction aiming conservation of the resource (Cadima, 2003). A range of controls, both economic and non-economic in nature, should be taken into account to ration the long-term utilization of marine resources (Clark, 1992). This drives the management of the demersal fisheries has to progress in attempt to solve the problem of heavily exploited which probably related to quasi-open access regime.

Across a broad range of species, $40 \%$ SPR is generally accepted as a proxy for Maximum Sustainable Yield, MSY (Prince et al., 2014), similar with the MSY estimation reported by Kalhoro (2013), and $50 \% S P R$ is generally accepted as a proxy for Maximum Economic Yield. Stocks are generally thought to risk recruitment decline when $S P R<20 \%$ (Ault et al., 2008). The values of SPR for the estimation of the present status of the Nomeifishery in Tarakan and the adjacent waters (based on research results during this period) following the ABARES Australia (Woodhams et al., 2012) can be depicted as three category of i.e : if SPR less than $25 \%$ the stock status at overfishing level; 25 to $40 \%$ nearly fully exploited and larger than $40 \%$ is under exploited level. Given that we found that the SPR at 28\% (Figure 4), therefore exploitation of this species currently being subjected to unsustainable rates of utilization and the result indicated that there would be a potential impact of highly effort pressures. By adjusting the minimum length at first capture from $20.8 \mathrm{~cm}$ to $22.0 \mathrm{~cm}$ (Figure 4 ) the level of theoretical SPR will also increased and it would be supported the biomass in long term harvesting.
To apply the SPR value actually depends upon the fisheries management objectives and the information available on the biological characteristics of the fish population. The fast growing species will likely be able to cope with higher fishing pressures. Hence, although the SPR's value is low, it is more likely that the fish stock will survive. Therefore, the various management measures for the Nomeifish in Tarakan and the adjacent waters could be initiated, for example, implementing minimum mesh size regulation, as such, the bigger the mesh size, the larger level of SPR value will be recover. This will help the stocks able to recover faster and may support a better long-term opportunity for coastal community livelihood.

International experiences show that due to their high productivity and rapid growth rates, some depleted fish stocks can recover quickly by simply restoring and maintaining breeding-size populations if fishing mortality is substantially reduced (Hilborn \& Litzinger 2009). The Nomeifisheries in Tarakan can be developed as a model for integrated management of coastal fisheries in the local region for several reasons. By using the biological characteristics of this species with fast growth rates of has a high resilience of a minimum population doubling less than 15 months (Fishbase, 2015). Another factor that necessary to be considered in management is the effect of spatial distribution of fishing effort with respect to change the reproductive potential stock in the near future. In-situ observation indicated that numbers of effort are densely operated in relatively narrow fishing grounds (Prasetyo et al., 2014), therefore high fishing pressure is likely occurred during fishing season in the area. These typical characteristics indicated that Nomei that may enable to quickly recover from overfishing with support the coherent communitybased organization nature of the home industry; and its reliance on sustainability-conscious domestic markets.

North Kalimantan Province is characterized by a small-scale demersal Danish seine fishery, and Nomei is one of their target species. These seine fisheries are often resulted in substantial 'by-catch' of undersized yet commercial-valuable fish species. These by-catch species often do not survive, even if returned to the sea. Such scrapping of the seabed thereby disturbs important soft-bottom habitats and may ultimately reduce marine biodiversity.

Interviewing with fishers indicated that the exploitation status, in general, indicated that tow operating time of this seine fishery tend to be longer during the last 10 years. Mesh size used were less 
than 1 " should be prohibited and maintained to apply the minimum mesh of $1.5^{\prime \prime}$ as stated by MMAF Minister Regulation No.2 /2011, article 24 on Fishing Zone and auxiliary gears for vessel size < 5GT. Operating in the area with depth of less than $5 \mathrm{~m}$ within fishing zone IA, which is covering coastal waters up to 2 (two) nautical miles, measured from water surface in the lowest tide should bestrictly not allowed.

\section{CONCLUSION}

Based on the undertaken observation, the calculated SPR of the Nomei fishery in the Tarakan and the adjacent waters, was estimated equivalent to $28.4 \%$. Given the SPR value of $28 \%$, Nomei fishery can be generally described as nearly fully exploited. These findings suggest that the sustainable development of this fishery could be best pursued through a rebuilding plan which should state in local fisheries management plan. Compliance with Ministerial Regulation on mesh size of equal or larger than 1.5 inch is not an option, it has to be performed by all trawl and seine fisheries in the area.

Several initiative action plans were already proposed during the consultative meeting with related stakeholders. Open and close fishing area to protect the nursery ground around the coastal waters of Bangkudulis (North of Tarakan estuarine waters) were also proposed to be designated under local government regulation.

\section{ACKNOWLEDGEMENT}

We are grateful for the financial support provided by the GEF-UNOPS in carrying out this project. We also would like to thank Research Institute for Marine Fisheries (RIMF) for comprehensive basic research activities that supported this project. We wish also to extend our gratitude to the many officials in all relevant local government institutions particularly the Tarakan City Marine Affairs and Fisheries Services (DKP) for their cooperation during our project activities. We also would like to thank to the lecture of Borneo Tarakan University especially for comments on Bombay duck fisheries in Tarakan and support for providing us with the relevant information on the existing fisheries.

\section{REFERENCES}

Abe, T \& D. Pathansali. 1974. Harpadontidae. In: W. Fischer \& P.J.P. Whitehead. FAO speciesidentification sheets for fishery purposes. Eastern Indian Ocean (fishing area 57) and Western Central Pacific. (fishing area 71). Vol. I, Rome FAO.
Ault, J.S., S.G. Smith, J. Luo, M.E. Monaco \& R.S. Appeldoorn. 2008. Length-based assessment of sustainability benchmarks for coral reef ûshes in Puerto Rico. Env. Conserv. 35 (3): p. 221-231.

Balli, J.J., S.K. Chakraborty \& A.K. Jaiswar. 2011. Population dynamics of Bombay duck Harpodon nehereus (Ham. 1822) (Teleostomi/Harpadontidae) from Mumbai waters, India. Indian J. of Geo-Mar. Sci. 40 (1): p. 67-70.

Bureau of Statistics Kalimantan Timur. 2012. Kalimantan Timur in Figure. 535 pp.

Berau of Statistics, Tarakan. 2012. Tarakan City in Figures. Kota Tarakan. 309 pp.

Cadima, E.L. 2003. Fish Stock Assessment Mannual. FAO. Fish. Tech. Pap. 393. 82 pp.

City Tarakan Government Regulation 04/2002. On Protecting Mangrove on Tarakan City.

Clark, J.R. 1992. Integrated management of coastal zones. FAO Fish. Tech. Pap.No. 327. 167 pp.

Directorat General of Capture Fisheries (DGCF). 2013. Capture Fisheries Statistics of Indonesia. 2012. 13 (1). Directorate General of Capture Fisheries. Ministry of Marine Affairs and Fisheries. Jakarta. $306 \mathrm{pp}$.

FAO. 2015. Global Capture Production (FishStat) Dataset.http://www.fao.org/ fishery/species/2949/ en. June $04^{\text {th }} 2015$. 10:00 local time.

Fishbase. 2015. http://www.fishbase.org/summary/ 260.April, $24^{\text {th }} 2015.10 .00$ wib.

Fisher, W \& G. Bianchi (eds). 1984. FAO species identification sheets for fisherypurposes. Western Indian Ocean; (Fishing Area 51). FAO. Rome.

Gulland, J.A \& A.A. Rosenberg. 1992. A review of length-base approaches to assessing fish stocks. FAO Fish. Tech. Pap. 100 pp.

Haneda, Y. 1950. Harpodon nehereus, a non-luminous fish. Pacific Sci., Vol. 4. April. p. 135-138.

Hilborn, R \& E. Litzinger. 2009. Causes of decline and potential for recovery of Atlantic cod populations. The Open Fish.Sci. Jour.,(2): p. 3238. 
Kalhoro, M.A., Liu Qun, K.H. Memon, M.S. Chang \& A.N. Jatt. 2013. Estimation of maximum sustainable yield of Nomei, Harpodon nehereusfishery in Pakistan using the CEDA and ASPIC packages. Pakistan J. Zool., Vol. 45 (6): p. 1757-1764.

Kohin, S., R. Conser \& G. Sakagawa. 2006. Biological reference points for use by Int'l. Sci. Comm. ISC/ 06/PLENARY/15.

Mustafa, M.G., M. Zafar, A.K.M.A. Matin \& S. Amin. M. N. 1998. Population dynamics of Harpodon nehereus (Ham-Buch.) from the Kutubdia channel of Bangladesh. Bangladesh J. Fish. Res., 2 (1): p. 83-90.

MMAF (Ministry of Marine Affairs and Fisheries) Regulation no. 42/2014. Fourth amendment on MMAF Regulation no. 2/2011 on Fishing Lane and auxiliary gear in Indonesian Fisheries Management Area. $17 \mathrm{pp}$.

Panggabean, A.S \& I.N. Idrus. 2013. Some biological aspects of Bombay-duck (Harpadon neherus Hamilton, 1822 in Tarakan Waters and its adjacent waters. In Exploitation Status of Fish Resource in North Sulawesi Waters (Suman et al., eds). Res. Inst. for Mar. Fish.Res. Rep. p. 121-135.

Prasetyo, A.P., D. Nugroho, Wudianto, Badrudin \& H.E. Irianto. 2014. The implementation of Tarakan East Kalimantan demonstration site of The SCSSFMP. Documentation for GEF/UNOPS Project Sulu-Celebes Sea Sustainable Fisheries Management Project. Research Center for Fisheries Management and Conservation, Final Project Report Jakarta. 112 pp [unpublished].

Prince, J., A. Hordyk, S.R. Valencia, N. Loneragan \& K. Sainsbury. 2014. Revisiting the concept of Beverton-Holt life-history invariants with the aim of informing data-poor ûsheries assessment. ICES J. of Mar. Sci., Advance Access published February 13, 2014. 10 pp.
Pusat Penelitian Pengelolaan Perikanan dan Konservasi Sumberdaya Ikan (P4KSI). 2013. Laporan Teknis: The Implementation of Tarakan East Kalimantan Demonstration site of the SCSSFMP. 54 pp. (Unpublished).

Shingadia, H.U. 2013. Seasonal variation in proximate composition of Nomei, Harpodon nehereus (HamBuch) from Mumbai Coast. Int. J. of Adv. Res. (2013), Volume 1, Issue 4: p. 52-55.

Sparre, P \& S.C. Venema. 1999. Introduction to tropical fish stock assessment. Vol. 1. FAO Fish.Tech. Pap. 306 (1). 376 pp.

Suprapto, Nurulludin \& B. Sadhotomo. 2015. Stock abundance of the Bombay-ducks fish (Harpodon nehereus) in Tarakan Waters (North Kalimantan). Indonesian J. Fish.Res. (in prep.).

Taufik, M., B. Sadhotomo, I.N. Edrus, A.S. Panggabean \& Suprapto. 2012. Annual Report. Study on demersal fish resources in the FMA 716 (Sulawesi Sea) and FMA 712 (Java Sea). RIMF. $226 \mathrm{pp}$.

Panggabean, A.S \& I.N. Edrus. 2012. Biological aspects of Nomei (Harpodon nehereus, Hamilton 1822) at Tarakan and adjacent Waters. RIMF. 30 pp. (Unpublished).

Ullah, H., D. Gibson, D. Knip, K. Zylich \& D. Zeller. 2014. Reconstruction of total marine fisheries catches for Bangladesh: 1950-2010. Work.Pap.Series. WP no. 2014-15. Fisheries Center. UBC.

Valencia, C.L \& O. Deffo. 1997. Evaluation of three length-based methods for estimating growth in tropical fishes: The red snapper Lutjanus campechanus of the Campeche Bank (Mexico). Sci. Mar., 61(3): p. 297-303.

Woodhams, J., I. Stobutzki, S. Vieira, R. Curtotti \& G.A. Begg (eds). 2011. Fishery status reports 2010: status of fish stocks and fisheries managed by the Australian Gov., ABARES, Canberra. 452 pp. 